\title{
The Effect of Basic Pencak Silat and Breathing Technique Practices on the Improvement of Physical Fitness in Male Athletes Viewed from Body Mass Index (An Experimental Study on Perguruan Pencak Silat Merpati Putih Maos Cilacap)
}

Eri kuswanti; Sugiyanto; Hanik Liskustyawati

Faculty of Sports Science, Postgraduate Program of Universitas Sebelas Maret, Surakarta, Indonesia

http://dx.doi.org/10.18415/ijmmu.v6i5.1120

\begin{abstract}
The objectives of research were: 1) to distinguish the effect of basic pencak silat (martial art) technique practice and the combined basic and breathing technique practice on the improvement of physical fitness, 2) to compare the improvement of physical fitness of athletes (pesilat) with lean and normal BMI. This study was an experimental research, with 20 male athletes being the sample. The sample taken was athletes aged 16-19 years belonging to adolescence period, constituting the good period for improving body size growth. The sample is divided into two experimental groups: basic technique group and basic and breathing techniques group. The physical fitness is measured based on BMI of Perguruan Merpati Putih Maos members, in which all sample members were measured for their body height and weight. Body Mass Index is a method employed to determine an individual's nutrition status. In adolescent, this determination is based on Body Mass Index (IMT) calculation and then matched with the growth chart corresponding to age and sex. Practice program was conducted 3 times a week for 8 weeks. The participants of two experiment groups did the practice according to their groups' treatment. Considering the result of Anova test, it could be found $p=0.000<0.05$ for basic and breathing technique movement and $\mathrm{p}=0.000<0.05$ for basic movement. This result indicated $\mathrm{p}<0.05$, meaning that Ho is not supported. It could be concluded that pencak silat basic technique practice program with the combined basic and breathing technique practices could improve physical fitness of Merpati Putih Maos Cilacap members more effectively.
\end{abstract}

Keywords: Basic Technique Practice; Breathing Practice; BMI; Merpati Putih; Physical Fitness

\section{Introduction}

Physical fitness is the degree of dynamic health that can support any activity in daily life without excessive fatigue, and the fatigue resolves before the same assignment or job come in the following day (Giriwijoyo, 2013: 49). It is in line with Nugroho (2010: 5) stating that physical fitness is an individual's body ability of doing daily chores without generating fatigue and still having energy reserve to enjoy leisure time and for sudden necessity. So, good physical fitness will support an individual in doing daily activities, thereby obtaining maximum result; with first-rate physical condition, an individual is expected 
to do his/her daily activity and gain good achievement. Physical fitness test is important to do in order to find out the physical fitness ability an athlete has. The result of physical fitness can be a reference in evaluating the strength and weakness of an athlete.

Merpati Putih practices breathing muscles including, among others, diaphragm muscles. Diaphragm is the main muscles used in the process of inhaling and exhaling Merpati Putih's breathing exercise practices breathing muscles by means of taking oxygen in as much as possible and hold the breath for about 40 seconds or 8 saps with maximum contraction, so that when breathing muscle is practiced continuously will allow the increase of oxygen intake capacity $\left(\mathrm{O}_{2}\right)$ in the lung. Perguruan Pencak Silat Betako Merpati Putih Kolat Maos (Pencak Silat School of Merpati Putih Empty-handed Martial Art of Maos Practicing Command) is one of pencak silat practice branch of Betako Merpati Putih in Maos area, in Dokteran Street No.48 Klapagada, Maos- Cilacap (0282) 695523, Central Java, with 20 male members being the sample. Considering the observation conducted in training center in Perguruan Pencak Silat Merpati Putih Kolat Maos, training center has practicing program just like other pencak silat training centers, including physical and technical practices, with less maximum practice periodicity.

Less maximum practice periodicity found during the observation includes unscheduled physical practice and technical practice in training center of perguruan pencak silat Betako Merpati Putih and inadequate practical frequency in a week. Perguruan Pencak Silat Merpati Putih has Merpati Putih breathing practice similar to yoga, as cited in Anas, Nortje (2016: 378-389), capable of improving VO2Max endurance and even the truth of which has been studied. But, training center of perguruan pencak silat Betako Merpati Putih kolat Maos uses Merpati Putih breathing practice rarely in each of its practices. Physical condition of training center athletes can be said as poor, because the result of physical fitness test (TKJI or Indonesian Physical Fitness Test) shows poor physical fitness of pencak silat merpati putih members.

For physical fitness purpose, the members of Merpati Putih kolat Maos do 60-m sprint, body hanging and lifting for 60 seconds, lying on and sitting down for 60 seconds, upright jump, and longdistance run $1200 \mathrm{~m}$. The result of research showed that many members of Merpati Putih Maos have poor physical fitness; thus, the physical fitness condition of Merpati Putih Maos's members is low.

This physical fitness of Merpati Putih is measured based on BMI among the members of Perguruan Merpati Putih Maos, in which all sample members will be measured for their body height and weight. Body Mass Index is a method used to determine an individual's nutrition status. In adolescent, this determination is based on Body Mass Index (IMT) calculation that is then matched with growth chart by age and sex.

Sample taken consisted of athletes aged 16-19 years, the age group belonging to adolescence period constituting the best period to improve the growth of body size, physical ability, and movement skill perfection. Pencak Silat Merpati Putih has basic movement and breathing practice pattern that can improve physical fitness. Handoyo (2005:40) states that to improve physical fitness, physical exercise can be done through stretching, warming-up, and breathing movement stages. Basic and breathing movement practices of Merpati Putih will activate the muscles. Handoyo (2005:88) stated that this merpati putih serves to activate the muscles by means of inhaling into the lung. This practice will get more maximum outcome as expected when it is conducted in programmed and structured manner.

Basic movement practice is an aerobic sport because the movement is continuous and lasts for more than 3 minutes while in breathing practice, it is an anaerobic sport because of its fast rhythm and duration for less than 3 minutes. Ambarukmi et al (2007: 7) stated that "aerobic energy system is the process to produce energy by requiring oxygen and basic material of glucose and glycogen through aerobic glycolisis; in addition, for the longer activity, fat and protein energy sources are required. 
Meanwhile an anaerobic system is the process of producing energy without oxygen". Therefore, the aerobic and anaerobic sports are equally important to the achievement of objective, to improve the physical fitness. Sukadiyanto and Muluk (2011:36) stated that "in early working ATP-PC energy system is indeed needed, but when the work proceeds continuously, another energy system is needed, in turn leading to aerobic energy system. So, both systems are inseparable absolutely during the muscle working activity.

Considering the background aforementioned, the author sees the need for studying further "The effect of basic martial art (pencak silat) technique and breathing practices on the improvement of physical fitness in male athletes viewed from BMI, an experimental study on Perguruan Pencak Silat Merpati Putih Maos Cilacap".

\section{Method}

This study was an experimental research with a 2 X 2 factorial design.

Table 1. A 2 X 2 Factorial Method

\begin{tabular}{ccc}
\hline & \multicolumn{2}{c}{ Components of Practice A } \\
\cline { 2 - 3 } BMI (B) & $\begin{array}{l}\text { LTGD } \\
\text { (A1) }\end{array}$ & LTGD and P (A2) \\
\hline normal (b1) & a1b1 & a2b1 \\
\hline lean (b2) & a1b2 & a2b2 \\
\hline
\end{tabular}

(Sugiyanto, 2013: 25)

Notes:

A1B1 : the group of merpati putih members with normal body mass index trained using basic technique practice

A1B2 : the group of merpati putih members with lean body mass index trained using basic technique practice

A2B1 : the group of merpati putih members with normal body mass index trained using basic and breathing technique practice

A2B2 : the group of merpati putih members with lean body mass index trained using basic and breathing technique practice.

In this research, there are two independent variables and one dependent variable studied. Manipulative independent or treatment variable is practice program (A). This variable consists of two levels: basic pencak silat technique practice (A1) and the combination of basic technique and breathing practices (A2). Attributive independent variable studied was Body Mass Index (B), consisting of two levels: good (B1) and poor body mass indexes (B2). The dependent variable was physical fitness (Y). There were two practice programs: Merpati Putih Basic Pencak Silat Technique and Merpati Putih Pencak Silat and Breathing technique, with two groups: group A (control group) treated with Merpati Putih Basic Pencak Silat technique and group B (treatment group) treated with Basic Pencak Silat and Breathing technique practice from Merpati Putih. BMI would be measured in both Groups A and B; BMI 
is the easiest way of estimating obesity and highly correlated with body fat mass, and important to identify an obese individual with medical complication risk. BMI has main advantages of representing excessive body fat simply and usable in a large-scale population research. Its measurement needs two components only: body weight and height, both of which can be done accurately by an individual with a little practice. The categorization of obesity level is of course based on BMI classification for adult in Indonesia according to Minister of Health's Decree No. 41/2014 about the Guideline of Served Balanced Nutrition.

Table 2. Classification of BMI Indicator for Indonesian adult

\begin{tabular}{llc}
\hline Classification & \multicolumn{1}{c}{ Category } & IMT $\left(\mathbf{k g} / \mathbf{m}^{\mathbf{2}}\right)$ \\
\hline \multirow{2}{*}{ Lean } & Severe Underweight & $<17.0$ \\
\multirow{2}{*}{ Normal } & Mild Overweight & $17.0-18.5$ \\
\multirow{2}{*}{ Fat } & & $18.5-25.0$ \\
& Mild Obesity & $>25.0-27.0$ \\
& Sever Obesity & $>27.0$ \\
\hline
\end{tabular}

(Minister of Health's Decree No. 41/2014 about the Guideline of Served Balanced Nutrition)

\section{Result and Discussion}

This study is an experimental research using quantitative approach aiming to compare two different treatments given to the subject of research using a factorial design technique. Table of normality test showed that data obtained from independent variable (physical fitness) is distributed normally. It is because the significance (p) of individual groups shows (p) or sig $>0.05$ meaning that $\mathrm{H} 0$ is supported, so that it can be concluded that data was taken from the normally distributed population. Homogeneity test was intended to examine the similarity of variance between groups, showing that the Levene's statistic significance value is 0.869 or more than 0.05 , so that it can be concluded that the data derived from homogeneous variant population.

\section{Estimates}

Dependent Variable: Physical Fitness

\begin{tabular}{|c|c|c|c|c|}
\hline \multirow[b]{2}{*}{ Practice Program } & \multirow[b]{2}{*}{ Mean } & \multirow[b]{2}{*}{$\begin{array}{l}\text { Std. } \\
\text { Error }\end{array}$} & \multicolumn{2}{|c|}{$\begin{array}{l}\text { 95\% Confidence } \\
\text { Interval }\end{array}$} \\
\hline & & & $\begin{array}{l}\text { Lower } \\
\text { Bound }\end{array}$ & $\begin{array}{l}\text { Upper } \\
\text { Bound }\end{array}$ \\
\hline Basic Technique Practice & 244.571 & 3.760 & 236.601 & 252.541 \\
\hline $\begin{array}{l}\text { Basic Technique and Breathing } \\
\text { Practice }\end{array}$ & 256.715 & 3.760 & 248.745 & 264.685 \\
\hline
\end{tabular}

In summary, the variance of individual group is equal or homogeneous. After the data is ascertained to be normal and homogeneous, hypothesis testing was then conducted using Anova test. Considering the table of hypothesis testing using Anova test, it can be seen that $\mathrm{p}$ basic technique and breathing $=0.000<0.05$. This result indicates $p<0.05$, meaning that Ho is not supported. Therefore, it 
can be concluded that there is a significant effect of the administration of basic technique practice and breathing practice on the improvement of physical fitness. The result of Anova test shows $\mathrm{p}$ basic technique $=0.000<0.05$, meaning that Ho is not supported.

Thus, it can be concluded that there is a significant effect of the administration of basic technique practice and breathing practice on the improvement of physical fitness. From the manual estimation considering the result of statistic descriptive, it can be seen that the administration of basic technique and breathing practices contribute to the improvement by $13.92 \%$ or higher than the administration of basic technique practice does, $5.38 \%$.

Basic technique practice intended in this study is similar to pencak silat technique in general, including basic Pencak Silat technique of Merpati Putih: basic stance (medium-center horse stance, lower center horse stance, leyek depan (leaning forward), leyek belakang (leaning backward), and pancer), stepping technique (left, front horse stance; right, front horse stance; change the step, stepping forward, stepping backward, side step forward, side step backward, facing right, facing left, about face, move forward, move backward), foot strike (forward kick, side kick, sickle kick, backward strike, pengkalan), hand defense technique (upper defense, lower defense, cut, swing), and hand strike technique (flat strike, cross strike, flat shovel, cross shovel, upper shovel, circling shovel, flat cut-down, flat fell, lower fell, totokan, flat elbow end). Doing basic technique practice will affect $\mathrm{O} 2$ consumption and $\mathrm{CO} 2$ production. It means that in doing this practice, there is an exchange of $\mathrm{O} 2$ (oxygen) and $\mathrm{CO} 2$ (carbon dioxide) between the air inside lung and the blood inside pulmonary capillary occurring through air pouch wall or alveolus. Basic technique practice is an aerobic sport due to its continuous technique lasting for more than 3 minutes. Candrawati et al (2016) in their journal shows that aerobic gymnastic exercise three times a week for 12 weeks can improve physical fitness affecting the pulmonary and hearth's flexibility and endurance.

Breathing intended in this research is breathing practice implemented in Pencak Silat Merpati Putih including, among others, garuda breath, push-pull, combination, energy exertion and electrical breath, conducted on sitting position, standing, and inside food on low horse-stance position. Breathing practice is an anaerobic sport due to its fast and sudden rhythm and duration less then 3 minutes. The technique used in breathing practice is similar to deep diaphragmatic breathing. Chistoph et al., (2011: 7280 ) in his research journal stated that diaphragmatic breathing is the breathing conducting with maximum inspiration through nose and gradual expiration through mouth. It can improve the performance of abdominal muscles contributing to expiration process. Furthermore, there is an increase in FEV (First Second Forced Expiration Volume) value due to abdominal respiration mechanism leading to the smooth reverse blood current from the vena around abdomen toward the heart that can impact on the increased pulmonary volume. Respiration tract deliver air from atmosphere to pulmonary part where the gas exchange occurs.

Physiologically, Nugroho (2006:1-15) stated that breathing practice by retaining and pressing the breath below the abdomen using a certain technique results in hypoxia (oxygen deficiency) in the lung, and then moving to the blood and ending up in all body tissue cells, particularly in active muscular cells, thereby will practice and stimulate all body cells through hypoxic mechanism in order to keep surviving in dealing with oxygen deficiency. Therefore, the cellular functions are getting better in normal oxygen condition. In breathing practice, the cells are fasted from oxygen during performing the jurus (technique) for 30-45 seconds. Thus, physiologically it can be stated that oxygen manipulation - making body cells oxygen-deficient is a very physiological way of stimulating the body cells to improve themselves. The result of research shows the different effects of experiment and control group practices on physical fitness because in experiment group, aerobic and anaerobic practices were used, but in control group only aerobic practice was used. 
Herman (2010) stated that aerobic change includes: increased myoglobin. Myoglobin is a pigment binding muscular $\mathrm{O} 2$ functioning to accumulate $\mathrm{O} 2$. Through the increase in carbohydrate oxidation, the practice increases muscular capacity to change glycogen into $\mathrm{CO} 2$ and $\mathrm{H} 20$ and ATP with oxygen help. The increased fat oxidation is due to energy accumulated in the fat about 40 times higher than the one accumulated in carbohydrate form. This increased fat oxidation ability is due to more fat accumulated in the muscles, the increased acid release, the increased fat-related enzyme activity and fat breaking. The change of anaerobic capacity involves the increased phosphacin (ATP-PC) capacity. This increase is due to more ATP-PC supply and more effective enzyme system necessary in ATP-PC system. The increased enzymes involve the increased ATP decomposition or reshaping.

\section{Conclusion}

1. There is an effect of the application of basic technique and breathing practices on the improvement of physical fitness significantly different from that of the application of basic technique practice only. So, the application of basic technique and breathing practice program improves the physical fitness better in male athletes of Pencak Silat in Merpati Putih Maos Cilacap.

2. There is a significantly different improvement of physical fitness between the basic pencak silat technique practice and the combination of basic technique and breathing practice, with significance level of $0.036<0.05$. The members of Merpati Putih with normal BMI improve their physical fitness better than those with lean BMI. Male athletes with normal BMI improve their physical fitness better than their counterpart with lean BMI.

3. There is a significant effect of the interaction between practice program and BMI on the improvement of physical fitness, with significance level of $0.134>0.05$. Both male athletes with normal BMI and those with lean BMI are treated with basic technique and breathing technique application to improve physical fitness.

\section{Recommendation}

To improve physical fitness, basic technique and breathing practices of Pencak Silat Merpati Putih can be used. Further study should be conducted on basic technique and breathing technique practices in order to provide broader result of experiment related to the result of study and this research can be input or comparator to further researchers. 


\section{References}

Candrawati, S.Sulistyoningrum, E, Bramantyo, D. Pranasari, N. 2016. Senam Aerobik Meningkatkan Daya Tahan Jantung Paru dan Fleksibilitas.Jurnal Kedokteran Brawijaya, 29 (1):69-73.

Christoph, T,A,Z. Yunus, F. Wiyono, W, H. 2011. Perbandingan Manfaat Klinis Senam Merpati Putih Dengan Senam Asma Indonesia pada Penyandang Asma.Departemen Pulmonologi dan Ilmu Kedokteran Respirasi FKUI / RS Persahabatan, 31 (2):77-80.

Comparasi, Implementasi dan Manajemen.Yogyakarta: FIK UNY. Nugroho, A. 2005.Melatih Sikap dan Gerak Dasar Pencak Silat bagi Pesilat Pemula. Jurnal Olahraga Prestasi, 1 (2):143-160.

Frankenfield D C, Rowe W A, Cooney R N, et al. Limits of body mass index to detect obesity and predict body composition. Nutrition, 2001; 17: 26-30.

Giriwoyo, S, H, Y, S \& Sidik, D, Z. 2013.Ilmu Faal Olahraga Fisiologi Olahraga.Bandung: PT Remaja Rosdakarya. Handoyo, A. 2005.Aplikasi Olah Napas. Jakarta: PT Elex Media Komputindo.

Hadisasmita. 1996. Ilmu Kepelatihan Dasar. Jakarta : Depetemen Pendidikan dan Kebudayaan Direktorat Jendral Pendidikan Tinggi.

Herman. 2010. Pengaruh Latihan terhadap Fungsi Otot dan Pernapasan.Jurusan Pendidikan Kepelatihan Olahraga FIK Universitas Negeri Makassar, 1 (2):27-32.

Irianto, Djoko Pekik. 2002. Diklat Dasar Kepelatihan .Yogyakarta : FIK UNY

Ismaryanti. 2008. Tes dan Pengukuran Olahraga. Surakarta : UNS Press.

Handoyo, A. 2005.Aplikasi Olah Napas. Jakarta: PT Elex Media Komputindo.

Karim, Faizati. 2002. Panduan Kesehatan Olahraga Bagi Petugas Kesehatan. Jakarta: Tim Departemen Kesehatan.

Kravitz, L. (1997). Panduan Lengkap Bugar Total.Jakarta : PT Raja Gravindo Persada.

Komarudin. 2013. Psikologi Olahraga. Bandung. : PT Remaja Rosdakarya.

Luminatuarso, Ria. Et al. 2013. Teori Kepelatihan Olahraga. Jakarta : Lankor.

Maksum, A.2012. Metodologi Penelitian dalam Olahraga. Surabaya: Unesa University Press.

Nala, N. 1998. Prinsip Pelatihan Fisik Olahraga. Denpasar: Universitas Udayana. Nugroho, A. 2004.Pencak Silat.

Nurmalina, Rina. 2011. Pencegahan \& Manajemen Obesitas. Bandung: Elex Media Komputindo.

Nugroho, A. 2004.Pencak Silat Comparasi, Implementasi dan Manajemen.Yogyakarta: FIK UNY.

Palar, C,M. Wongkar, D. Ticoalu, S,H,R. 2015. Manfaat Latihan Olahraga Aerobik terhadap Kebugaran Fisik Manusia. Jurnal e-Biomedik (eBm), 3 (1):316-321. Sukadiyanto dan Muluk, D. 2011.Pengantar Teori dan Metodologi Melatih Fisik. Bandung: Lubuk Agung. 
Sharkey, Brian J. 2011. Kebugaran dan Kesehatan.Jakarta: Rajawali Pers. p 277-279.

Sukadiyanto dan Muluk, D. 2011.Pengantar Teori dan Metodologi Melatih Fisik. Bandung: Lubuk Agung.

Sugiyono. 2005. Memahami Penelitian Kualitatif. Bandung : Alfabeta.

Sugiyanto. 1996. Perkembangan dan Belajar Motorik. Jakarta : Departemnen Pendidikan dan Kebudayaan. Direktorat Pendidikan Dasar dan Menengah. Direktorat Guru dan Tenaga Bagian Penataran Guru Pendidikan Jasmani dan Kesehatan SD Setara D II.

Widiastuti. 2015. Tes dan Pengukuran Olahraga. Jakarta.: Rajawali Pers.

Wiyono, Bambang, Budi \& Sunarni, 2009.Evaluasi Program Pendidikan dan Pembelajaran.Malang : Pendidikan Universitas Negeri Semarang.

\section{Copyrights}

Copyright for this article is retained by the author(s), with first publication rights granted to the journal.

This is an open-access article distributed under the terms and conditions of the Creative Commons Attribution license (http://creativecommons.org/licenses/by/4.0/). 